DOI: $10.4274 /$ tftr. 14880

\title{
Pearson Sendromlu Bir Olguda Mitokondrial Miyopati Rehabilitasyonu
} Mitochondrial Myopathy Rehabilitation in a Case of Pearson Syndrome

\author{
Güzide BATUR, Fikriye Figen AYHAN, Bülent ALIOĞLU*, Müyesser OKUMUŞ, Pınar BORMAN \\ S.B. Ankara Eğitim ve Araştırma Hastanesi 1. Fizik Tedavi ve Rehabilitasyon Kliniği, Ankara, Türkiye \\ *S.B. Ankara Eğitim ve Araştırma Hastanesi Çocuk Hematoloji Bölümü, Ankara, Türkiye
}

Özet

Pearson sendromu kemik iliği prekürsörlerinin vakuolizasyonu, refrakter sideroblastik anemi ve metabolik asidozla karakterize nadir görülen ve sıklıkla fatal bir mitokondrial hastalıktır. Bugüne kadar 70'ten fazla hasta yayınlanmıştır, ama egzersizin etkisi bildirilmemiştir. Erkek/kadın oranı $0,7^{\prime}$ dir. Kalıım maternaldir çünkü mitokondri ovumda ve fertilizasyon öncesi spermin kuyruğunda bulunur. Akrabalarda da hastalık görülebilir. $\mathrm{Bu}$ olgu sunumunda, Pearson sendromu olan 22 yaşındaki bir kadın hastayı sunduk ve mitokondrial miyopati rehabilitasyonu yaklaşımlarını özetledik. Türk Fiz Tıp Rehab Derg 2011;57 Özel Sayı 2: 341-4.

Anahtar Kelimeler: Pearson sendromu, mitokondrial miyopati, rehabilitasyon

\begin{abstract}
Pearson syndrome is an often fatal and rarely seen mitochondrial disorder characterized by vacuolization of bone marrow precursors, refractory sideroblastic anemia and metabolic acidosis. More than 70 cases have been published, but the effect of exercise on Pearson syndrome has not been reported yet. Male/female ratio is 0.7 . Inheritance is maternal because mitochondria are found in the ovum and tail of the sperm before fertilization. The syndrome may also be seen among relatives. In this case report, we presented a 22-year-old female patient with Pearson syndrome and summarized the rehabilitation approaches in the treatment of mitochondrial myopathy. Turk J Phys Med Rehab 2011;57 Suppl 2: 341-4. Key Words: Pearson syndrome, mitochondrial myopathy, rehabilitation
\end{abstract}

\section{Giriş}

Pearson sendromu (PS), ilk kez 1979 'da Dr. Howard Pearson tarafından kemik iliği vakuolizasyonuna eşlik eden refrakter sideroblastik anemi ve ekzokrin pankreatik disfonksiyonu olan dört olguda tanımlanmıştır. Mitokondrial DNA'nın patognomonik delesyonu metabolik asidoz ve anemiyi kapsayan sendromun klinik özelliklerini açıklamak ve moleküler tanı sağlamak amacıyla 1990 'da Rotig ve arkadaşları tarafından ortaya konmuştur. Bugüne kadar 70'ten fazla hasta yayınlanmıştır. Erkek/kadın oranı 0,7'dir. Kalıtım maternaldir çünkü mitokondri ovumda bulunur ama spermin kuyruğunda bulunan mitokondri fertilizasyon sırasında kuyrukla birlikte düşünce embriyoya geçemez. Akrabalarda da hastalık görülebilir veya annede Kearns-Sayre sendromu (KSS) (oftalmopleji, pigmente retinopati, ataksi, kalpte iletim bloğu ve endokrinopati) olabilir. Tüm ırklardan hastalar rapor edilmiştir (1). $\mathrm{Bu}$ olgu sunumunda nadir görülen PS'li bir olgu tanıtılacak ve mitokondrial miyopatide rehabilitasyon yaklaşımları güncel bilgiler ışığında özetlenecektir.

\section{Olgu Sunumu}

Yirmi iki yaşında kadın hasta yürüyüş bozukluğu, yürümede ve merdiven çıkmada zorluk şikayetiyle polikliniğimize başvurdu. Öyküde, ilk yürümeye başladığı zaman yürümesinin normal olduğu, ilkokula başladığında yürüyünce yorulduğu ve sık sık 
dinlenmek istediği ve 15 yaşında yürüyüşünde bozulma olduğu; merdiven çıkarken sol dizini eliyle desteklemek zorunda kaldığı öğrenildi. Daha önce zaman zaman acil servise başvurduğunu, laktik asidoz tespit edildiğini, yapılan muayene ve tetkikler neticesinde 19 yaşında çocuk hematolojisi tarafından PS tanısı konulduğunu ifade etti. Çocuk hematolojisi tarafından yapılan kemik iliği aspirasyon biyopsisinde megaloblastik değişiklikler, eritroid ve miyeloid seride yer yer vakuolizasyon olduğu tespit edilmişti.

Özgeçmişinde, biküspit aort darlığı nedeniyle aort kapak replasmanı ve sağ gözde şaşıllık operasyonu öyküsü mevcuttu. Diare atakları nedeniyle gittiği gastroenteroloji polikliniğinde yapılan endoskopide gastrit ve Çölyak hastalığı saptanmıştı. Yapılan EMG'de sağ tibialis anterior, medial gastroknemius ve sol tibialis anterior kaslarında düşük amplitüdlü polifazik Motor Ünite Potansiyeller izlenmişti. Sağ vastus lateralis ve deltoid kasları iğne elektromyografi (EMG)'si normaldi. EMG'de distal tip miyopati ekarte edilemediği için kas biyopsisi önerildiği belirlendi. Kas biyopsisinde, gomori trikrom boyamasında liflerin periferinde anormal mitokondrial birikimle uyumlu 'ragged red fiber' görünümü olduğu, kesitlerde kas lifleri arasında hafif çap farkı, bazı liflerde düzensiz boyanma raporlanmıştı. Bu biyopsi sonucu ile mitokondrial hastalık tanııı doğrulanmış̧ı. Soygeçmişte erkek kardeşine de PS ve Çölyak Hastalığı tanısı konduğu öğrenildi.

Hastanın fizik muayenesinde genel durumu iyi, bilinci açı, oryante ve koopereydi. Kardiyovasküler sistem muayenesinde oskültasyonda metalik kapak sesi ve aort odağında sistolik üfürümü mevcuttu. Solunum sistemi ve batın muayenesi normaldi. Lokomotor sistem muayenesinde postür analizinde lomber lordoz artmıştı. Üst ve alt ekstremite ile gövde eklem hareket açıkııları normaldi. Yürüme analizinde adım açıklığı artmıştı ve adım uzunluğunda kısalma mevcuttu, basma fazında sağ ayak pronasyonda ve sağ kalça internal rotasyondaydı, merdiven çıkarken dizlerini kilitlemek için ellerinden destek almaktaydı. Kranial sinirlerin muayenesi ve serebellar testler normaldi. Aşırı kullanıma bağlı kas güçsüzlüğünü önlemek için üst ekstremite, gövde ve alt ekstremite manuel kas testi değerlendirmesi iki güne eşit bir şekilde bölündü. Manuel kas testi (Medical Research Council'e göre) rehabilitasyon öncesi ve sonrasında, önceki değerlendirmesini görmeksizin aynı fizyoterapist tarafından yapıldı. Yapılan manuel kas testi muayenesinde omuz fleksörleri rehabilitasyon öncesi (RÖ): 4+, rehabilitasyon sonrası (RS): 5 kuvvetinde; sağ ve sol triceps RÖ: 4, RS: 5 kuvvetinde; kuadratus lumborum RÖ: 3, RS: 4 kuvvetinde; sağ kalça fleksörleri RÖ: 4-, RS: 4+ kuvvetinde; sol kalça fleksörleri RÖ: 4+, RS: 5 kuvvetinde; sağ ve sol kalça ekstansörleri RÖ: 2+, RS: 4 kuvvetinde; sağ ve sol hamstring RÖ: 4-, RS: 4+ kuvvetinde; sağ kuadriceps RÖ: 4+, RS: 5 kuvvetinde; sol kalça addüktörleri RÖ: 3+, RS: 4+ kuvvetinde; sağ kalça internal rotatorları RÖ: 4-, RS: 4 kuvvetinde; sağ kalça eksternal rotatorları RÖ: 4-, RS: 4+ kuvvetinde; sol kalça eksternal rotatorları RÖ: 4, RS: 4+ kuvvetinde; sağ ve sol sartorius RÖ: 3, RS: 4 kuvvetinde bulundu. Diğer kasların [(sağ ve sol omuz ekstansörleri (4+), abdüktörleri, internal ve eksternal rotatorları (4+), biseps braki (4+), el bileği fleksörler ve ekstansörleri (5), parmak abdüktör (4) ve addüktörleri (4-), sağ ve sol lateral abdominal (3), lomber ekstansörler (3), sol kuadriceps (4+), sağ ve sol tibialis anterior (5), peroneal (5), sağ ve sol kalça abdüktörleri (4), sağ ve sol gastrosoleus (5), fleksör ve ekstansör hallusisler (5)] RÖ ve RS kas kuvvetleri aynı saptandı.

Laboratuvar incelemelerinde WBC: $5800 / \mathrm{mL}$, RBC: $2890000 / \mathrm{mL}$, PLT: $198000 / \mathrm{mL}, \mathrm{Hb}: 9,5 \mathrm{~g} / \mathrm{dL} \mathrm{Hct:} \% 27$,4, eritrosit sedimentasyon hızı: $11 \mathrm{~mm} / \mathrm{saat}$, PT INR: 2,43 değerlerindeydi. Biyokimyasal incelemeler glukoz: $71 \mathrm{mg} / \mathrm{dL}$ (75-100), üre: $14 \mathrm{mg} / \mathrm{dL}$ (17-43), kreatinin: 0,41 mg/dL $(0,81-1,44)$, LDH: 270 U/L (0-248), LDL: 39 $\mathrm{mg} / \mathrm{dL}$ (60-130) dışında normal düzeylerdeydi.

Hastanın yapılan solunum fonksiyon testinde FEV1 \%92, FEV1/FVC \%109, VC \%91 ve maksimum istemli ventilasyon (MVV) \%66,8 olarak bulundu. Hastanın MVV değeri normalden düşüktü.

Hasta farmakolojik tedavi olarak coumadin $5 \mathrm{mg} 1 \times 1,5 \mathrm{tb}$,

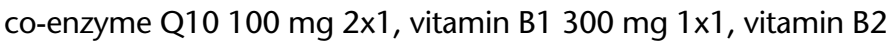
$50 \mathrm{mg}$, carnitine $1 \mathrm{gr} 1 \times 1$, becozyme $C$ (vitamin B1 (tiamin) $15 \mathrm{mg}$, vitamin B2 (riboflavin) $15 \mathrm{mg}$, vitamin B6 (piridoksin) $10 \mathrm{mg}$, vitamin B12 (siyanokobalamin) $10 \mathrm{mcg}$, kalsiyum pantotenat $25 \mathrm{mg}$, vitamin B9 (folik asit) $1,5 \mathrm{mg}$, vitamin C (askorbik asit) $200 \mathrm{mg}$, d-biotin $0,15 \mathrm{mg}$, nikotinamid (niasinamid) $50 \mathrm{mg}$ ) 2x1 kullanmaktaydı.

Hasta miyopati rehabilitasyon programı almak üzere servise yatııldı. Miyopati rehabilitasyonu ve aerobik egzersiz programına alınan hastada akşamları olan spontan burun kanamaları nedeniyle hematoloji konsültasyonuyla coumadin tedavisi kesildi. Düşük molekül ağırlıkı fraksiyone heparin $0,4 \mathrm{ml} 1 \times 1 \mathrm{sc}$ uygulamasına geçildi. Hasta 10 seans fizik tedavi ve miyopati rehabilitasyon programı aldı. Hastanın ilgili eklemini çalışıran kas gücüne göre 3 ve altı olan kaslara pasif eklem hareket açıklığı egzersizi, 3+ olan kaslara aktif-asistif eklem hareket açıklığı egzersizi, 4 ve 5 olan kaslara aktif eklem hareket açıklı̆ı̆ egzersizi seçildi. Hastaya önce paralel barda ve ayna karşısında postür, yürüme ve denge-koordinasyon egzersiz programı uygulandı, daha sonra egzersizlerine paralel bar dışında devam edildi. Hasta tolere edebildiği ölçüde (yorgunluk gelişene kadar) aerobik egzersiz (sabit bisiklet) programına alındı.

Iki hafta miyopati rehabilitasyon programı ve tolere edebildiği düzeyde aerobik egzersiz eğitimi ve ev programı verilen hastanın hastaneden çıktıktan altı hafta sonra (rehabilitasyon süreci sonrasında oluşabilecek kas gücü değişikliğini gözlemleyebilmek için gereken süre) yürüme testi ve manuel kas testi tekrarlandı. Ev programında hastaya haftada üç gün yürüme, eklem hareket açıklı̆ı ıgzersizleri ve izometrik egzersizler verildi.

Rehabilitasyon programı öncesi aerobik performansı belirlemek için yapılan yürüme testinde hastamız $1 \mathrm{dk} 13$ sn yürüyebildi, ortalama 46 m yürüdü (hız 40,7 m/dk); yürüme öncesi TA: 100/60 $\mathrm{mm} \mathrm{Hg}$, nabız 92, solunum sayısı 25 , yürüme sonrası TA: $110 / 70$ $\mathrm{mm} \mathrm{Hg}$ nabız 92, solunum sayısı 20 olarak saptandı.

Rehabilitasyon programı sonrası 6 . haftada yürüme testinde hastamızın 2 dk 2 sn yürüyebildi, ortalama 76 m yürüdü (hız 34,5 $\mathrm{m} / \mathrm{dk}$ ); yürüme öncesinde TA: $90 / 60 \mathrm{~mm} \mathrm{Hg}$, nabız 80 , solunum sayısı 34; yürüme sonrasında TA: $110 / 80 \mathrm{~mm} \mathrm{Hg}$, nabız 74, solunum sayısı 34 olarak saptandı. 


\section{Tartışma}

Pearson kemik iliği-pankreas sendromu, ekzokrin pankreatik disfonksiyon ve kemik iliği prekürsörlerinin vakuolizasyonu ve refrakter sideroblastik anemiyle karakterize sıklıkla fatal olan infantil kemik iliği yetmezliği sendromudur. Mitokondrial DNA'da (mtDNA) yalnız büyük ölçekli delesyon/duplikasyonların birikimi görülür. PS'de, mtDNA'nın nokta mutasyonları bildirilmemiştir. Bu hastalık mitokondrial oksidatif fosforilasyonun yaygın oksidatif defektiyle sonuçlanır (2-4).

Her organ sisteminin yaş ve aktivitesiyle de ilişkili olarak, değişik oranlarda mitokondrial enerjiye ihtiyacı vardır ve her sistem farklı miktarlarda mitokondri içerir. Yine her doku farklı miktarlarda normal ve mutant mitokondrial DNA içerir. Dokuda mutant genomların oranı ne kadar fazla ise ATP üretimi o denli yetersizleşir ve doku-organ disfonksiyonları başlar. Doku veya organın enerji metabolizmasında yetersizliğe yol açacak, disfonksiyona neden olacak minimum mutant mtDNA miktarına eşik etkisi (threshold effect) denir. Eşik etkisi, doku ve yaşa göre değişir. Örneğin beyin ve kas hücreleri daha fazla enerji ihtiyacı içindedir ve gelişmekte olan çocuklarda daha aktiftir. Bu organlarda düşük miktarda mutant mtDNA semptomatik olabilirken, daha yüksek oranda mutant mtDNA örneğin karaciğerde semptom vermeyebilir. Sonuçta, mutant ve normal genomlarin oranı, doku tipi, yaş, enerji ihtiyacı gibi faktörler fenotipi belirleyerek mitokondrial hastalık dediğimiz bir grup hastalığa neden olur (5).

PS hastalarının 1/3'ünde düşük doğum ağırlığı öyküsü vardır ve metabolik asidoz yaygındır. Fiziksel anomaliler nadirdir. Yaklaşık olarak hastaların 1/3'ünde ekzokrin pankreas yetmezliği vardır ve insüline bağımlı diyabet gelişimi yaygındır. Renal hastalık, karaciğer yetmezliği ve hipoparatiroidizm de görülebilir. Ortalama hemoglobin $(\mathrm{Hb})$ seviyesi 5,8 gr/dL'dir. Olguların yarısında nötrofil sayımı 500/mL'den, platelet sayımı $100.000 / \mathrm{mL}^{\prime}$ den azdır. Tüm hastaların kemik iliğinde myeloid ve eritroid prekürsörleri vakuolizedir, birçoğunda eritroblast azalmıştır ve hepsi sideroblast ve çoğu ring sideroblasttır. Altı yaşa gelen hastalarda yürüme problemleri, egzersiz intoleransı, kısa boy, dermatolojik problemler ve rekürren enfeksiyonlar gelişir $(1,6-8)$. Bizim hastamızda da anemi, laktik asidoz ve kemik iliği aspiratında miyeloid ve eritroid seride vakuolizasyon ve megaloblastik değişiklikler, yürüme problemi, egzersiz intoleransı ve büyüme geriliği mevcuttu. Ama diyabet ve ekzokrin pankreas yetmezliği yoktu.

PS'de majör problem asidozdur. Spesifik terapinin amacı ko-enzim Q, L-karnitin, riboflavin, tiaminin kullanımıyla respiratuvar enzimleri by-pass etmektir (1). Mitokondrial hastalıklarda kan hücrelerinin tutulumunun tedavisi antioksidan, vitaminler, demir, kemik iliği stimüle edici faktörler veya hücrelerin yerine konması şeklinde uygulanmaktadır (9).

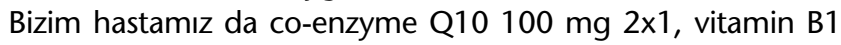
$300 \mathrm{mg} 1 \times 1$, vitamin B2 $50 \mathrm{mg}$, carnitine $1 \mathrm{gr} 1 \times 1$ becozyme $C$ (vitamin B1 (tiamin) $15 \mathrm{mg}$, vitamin B2 (riboflavin) $15 \mathrm{mg}$, vitamin B6 (piridoksin) 10 mg, vitamin B12 (siyanokobalamin) $10 \mathrm{mcg}$, kalsiyum pantotenat $25 \mathrm{mg}$, vitamin B9 (folik asit) 1,5 $\mathrm{mg}$, vitamin C (askorbik asit) $200 \mathrm{mg}$, d-biotin 0,15 mg, nikotinamid (niasinamid) $50 \mathrm{mg}$ ) 2x1 kullanmaktaydı.

PS'de 2,7-7,767 kb aralığında mitokondrial DNA delesyonunun tüm hastalarda belirlendiği bildirilmiştir. Respiratuar enzimleri kapsayan delesyonlar azalmış NADH, sitokrom oksidaz,
ATPaz hem tRNA hem de ribozomal RNA'yı içermektedir. Hastalığın sebebi çoğunda sıklıkla de novo delesyon ya da daha nadiren mitokondrial DNA duplikasyonudur. Bazı vakalarda delesyonla duplikasyonlar bir aradadır (1).

Hastamıza genetik analiz yapılmamıştır. PS tanısı, klinik bulgular ve kemik iliği biyopsisi ile mitokondrial miyopati tanısı kas biyopsisi ile konmuştur. Yürüme ve postür eğitimi ile birlikte miyopati rehabilitasyonu amacıyla kliniğimizde hospitalize edilmiştir.

PS'de ölüm asidoz, renal ve karaciğer bozukluğu, sepsis ve kalp bloğuna bağlıdır ve genellikle aplastik anemiden değildir. Tedavi genellikle destekleyicidir ve hastalık genellikle fataldir. Tahmini yaşam süresi 10 yaşta \%36 platoyla ortalama dört yıldır $(1,7)$. Bizim hastamız 22, kardeşi 13 yaşındaydı. PS tanılarını 19 ve 10 yaşlarında almışlardı. PS semptomları 7-8 yaş civarı başlamış. 15 yaş civarında yürüme güçlüğü aşikar hale gelmişti.

Egzersiz intoleransı mitokondrial miyopatili hastalarda en yaygın semptomlardan biridir. Tüm vücut düzeyinde yoğun egzersiz alanlarda hiperdinamik dolaşım cevabı aşırı CO2 üretimi (VCO2) ve maksimal oksijen tüketiminde (VO2max) azalmayla karakterizedir. Klasik olarak egzersiz toleransı VO2, VCO2, anaerobik eşik ölçümlerini içeren ergospirometre kullanılarak saptanır (10). Hastamız yürüme testi iyi olmadığı için ergospirometrik değerlendirmeye alınamadı.

Birçok nöromuskuler hastalığın bir arada değerlendirilmesi sonucunda birçok araştırmacı düzenli bisiklet eğitiminden sonra oksijen kullanımını arttığını, submaksimal iş yükü ile kalp hızının azaldığını göstermişlerdir. İki araştırmada inflamatuvar miyoziti olan olgularda aerobik performansı arttırmak amacı ile planlanmayan güçlendirme ve aerobik egzersizlerin (düzenli bisiklet ve step aerobik) oksijen kullanımını arttırdığı bildirilmiştir (11). Bizim hastamızda da rehabilitasyon sonrası solunum sayısı artmış ve kalp hızı azalmıştı.

Literatürde PS'de, egzersiz ve rehabilitasyonla ilgili yayın bulunmamaktadır. Yapılan bir çalışmada mitokondrial miyopatili hastalarda kısa-dönem aerobik egzersiz eğitiminin yararlı olduğu gösterilmiştir. Mitokondrial miyopatili hastaların kısa dönem aerobik eğitime cevabı nonmetabolik miyopatili hastalar ve sedanter normal kişilerle karşılaştııılmış ve aerobik kapasitede artışın mitokondrial miyopatili hastalarda diğer iki gruba göre daha fazla olduğu gösterilmiştir. Bu çalışmada aerobik egzersiz eğitimi maksimum kalp hızının \%70-85'inde korunduğu treadmill ile 8 hafta uygulanmıştır (12). Mitokondrial miyopatisi olan hastalarda yapılan bir çalışmada 12 hafta yapılan egzersiz tedavisinin kas metabolizması ve fiziksel fonksiyonda etkili olduğu gösterilmiştir. Mitokondrial miyopatili hastalarda kas aktivitesi boyunca sitozolik adenozin difosfat konsantrasyonunda değişikliklerle birlikte mitokondrinin bozulmuş duyarlılığı, anaerobik enerji yoluna artmış bağımlılık ve proton akışında adaptif artış vardır. Egzersiz tedavisi sonrası, mitokondrial fonksiyon ve kas kütlesinde proton akış oranında herhangi bir değişiklik olmaksızın iyileşme görülmüştür (13). Mitokondrial miyopatili hastalar ve kontrol grubu arasında yaş, cinsiyet ve fiziksel aktiviteden bağımsız önemli metabolik farklılıklar olduğu ve egzersiz tedavisinin mitokondrial miyopatili hastalarda mitokondrial fonksiyonların iyileşmesine yardımcı olabileceği belirtilmiştir. Bizim hastamız iki haftalık miyopati rehabilitasyonu ve aerobik egzersiz eğitimine ev programı (bisiklet çevirme, haftada üç gün yürüme ve eklem hareket açıklığı egzersizleri) ile devam etti. Altı hafta sonraki yürüme testinde yürüme süresinde $\% 67$, yürüme mesafesinde $\% 65$ artış kaydedildi. 
Klasik olarak miyopatilerde rehabilitasyon üç devrede ele alınır: Ambulatuvar (erken) evre, tekerlekli sandalye evresi ve geç evre.

Ambulatuvar (erken) evrede tedavi hedefleri mobiliteyi sürdürmek, kontraktürleri önlemek ve fonksiyonel bağımsızlık süresini mümkün olduğunca uzatmaktır. Tanı konduktan sonra hastaya ve ailesine, tedavi ekibi tedavinin her basamağında psikolojik destek sağlamalıdır. Hastanın kas kuvvet kaybı ve muskulotendinöz gelişimi dikkatle izlenmelidir. Manuel test ile kas kuvvet kaybı izlenerek hastalığın progresyon hızı ve prognozu belirlenebilir. Kas kuvveti kaybı yılda \%10'un üzerinde ise hastalığın seyri hızlıdır. Çocuk sırt üstü konumdan oturma pozisyonuna gelemiyorsa kas kuvvetinin \%50'si kaybedilmiştir.

Tipik olarak manuel kas testi kullanılırsa da hastalığın progresyonunu değerlendirmedeki rolü sınırlıdır, endurans ve yorgunluğu değerlendiremez. Daha duyarlı olan kantitatif yöntemlerle statik izometrik, dinamik izokinetik güç, yorgunluk ve endurans ölçülebilmektedir. Hangi nedenle olursa olsun bir kas zayıflığı söz konusu ise genel yaklaşım 'kuvvetlendirme egzersizleri' dir. Ancak nöromuskuler hastalıklarda kuvvetlendirme egzersizlerini takiben kuvvetsizliğin artabildiği bilinmektedir. Bu aşırı kullanıma bağlı (overuse) bağlı kas lifi dejenerasyonudur. Daha çok hızlı progresyon gösteren veya çok ileri kas güçsüzlüğü olan, yüksek dirençli anaerobik egzersizlerin ve eksantrik egzersizlerin yapıldığı olgularda görülür. Kuvvetlendirme egzersizleri yoğunluk ve süre olarak submaksimal düzeyde olmalı ve aşırı kullanıma bağlı kuvvetsizlik gelişmesi önlenmelidir. Hasta tolere edebildiği oranda aerobik, yüksek tekrarlı egzersizlere teşvik edilmelidir. Aerobik egzersizler kardiyopulmoner ve muskuler sisteme yararlı bir stimulus sağlayacak düzeyde ancak enerjinin primer kaynağı olan anaerobik eşiğin altında olan ritmi uzun aktivitelerdir. Nöromuskuler egzersizlerde uyulması gereken kurallar:

1. Egzersizler hastalığın erken döneminde başlamalıdır.

2. Yavaş progresyon gösteren veya statik hastalarda yapılmalıdır.

3. Submaksimal güçle yapılan çok tekrarlı aerobik egzersizler uygulanmalıdır.

En önemli kontraktürler ayak bileğinde plantar fleksiyon, diz ve kalçada fleksiyon, iliotibial bant, dirsek ve el bileği fleksiyon kontraktürleridir. Manuel kas testi ile 3 ve üstü ekstansör kas gücü olanlarda fleksiyon kontraktürü gelişiminin nadir olduğu bildirilmiştir. Hastalar ambule iken kontraktürler nadirdir, tekerlekli sandalyeye bağımlılıkla kuvvetle ilişkilidir. Erken tanı ve fizik tedavinin erken başlatılması önemlidir. Illerlemiş kontraktürler fikse hale geldiği zaman germe egzersizlerine cevap vermezler.

Tekerlekli sandalye devresinde ise skolyoz, alt ekstremite kontraktürleri, bası yaraları, obezite ve kardiyak komplikasyonlar başa çıkılması gereken sorunlardır. Düzenli olarak Holter monitörü ve ekokardiyografi ile takip gereklidir. Ventriküler ejeksiyon fraksiyonu \%20'nin altına düşerse prognoz kötüdür. Günlük yaşam aktivitelerini kolaylaştıracak çeşitli yardımcı aletler önerilir:

Geç devrede ise genel tıbbi bakım ve hemşirelik hizmetleri önemlidir. Ana sorunlar respiratuvar ve kardiyak sistemle ilgilidir. Respiratuvar yetmezlik önemli bir ölüm sebebidir. Kas güçsüzlüğü ilerledikçe ventilasyon desteği için gerekli süre artar ve hatta tüm gün destek gerekebilir (14).
Bizim hastamız ambulatuvar evredeydi. Bu dönemde tedavi hedefleri mobiliteyi sürdürmek, kontraktürleri önlemek ve fonksiyonel bağımsızlık süresini mümkün olduğunca uzatmaktır. Tanı konduktan sonra tedavi ekibi hastaya ve ailesine, tedavinin her basamağında psikolojik destek sağlamalıdır.

Kuvvetlendirme egzersizleri, yoğunluk ve süre olarak submaksimal düzeyde olmalı ve aşırı kullanıma bağlı kuvvetsizlik gelişmesi önlenmelidir. Hasta tolere edebildiği oranda aerobik, yüksek tekrarlı egzersizlere teşvik edilmelidir. Bu programı alan hastamızda, özellikle güçsüz olan proksimal alt ekstremite kaslarında manuel kas testindeki kas gücünde artış olduğunu ve yürüme mesafesi ile yürüme süresinin arttığını belirledik.

Sonuç olarak, refrakter sideroblastik anemili hastalarda nadir bir tanı olan PS akla gelmelidir. Diğer mitokondrial miyopatilerde olduğu gibi PS'li hastalara da günlük yaşam aktiviteleri ve mobilitenin devamı için miyopati rehabilitasyonu programını takiben aerobik egzersiz reçetesi verilmelidir.

\section{Kaynaklar}

1. Alter BP. Inherited bone marrow failure syndromes. In: Orkin $S$, Nathan D, Ginsburg D, Look T, Fisher D, Lux S, editors. Nathan and Oski's Hematology of infancy and childhood. 6th ed. Philadelphia, PA: Saunders; 2003. p. 280-365.

2. Munakata K, Bundo M, Kato T, Ono H, Sakura N, Oosaki M, et al. CoExisting point mutations of mitochondrial DNA in a patient with a heart abnormality and Pearson syndrome-like symptoms. Am J Med Genet A 2005;139:162-5.

3. Muraki K, Nishimura S, Goto Y, Nonoka I, Sakura N, Ueda K. The association between hematological manifestation and mtDNA deletions in Pearson Syndrome. J Inherit Metab Dis 1997;20:697-703.

4. Gürgey A, Özalp I, Rötig A, Coşkun T, Tekinalp G, Erdem G, et al. A case of Pearson syndrome associated with multipl renal cysts. Pediatr Nephrol 1996;10:637-8.

5. www.genbilim.com/content/view/39/32/

6. Seneca S, De Meirleir L, De Schepper J, Balduck N, Jochmans K, Liebaers I, et al. Pearson marrow pancreas syndrome: a molecular study and clinical management. Clin Genet 1997;51:338-42.

7. Cursiefen $C$, Küchle M, Scheurlen W, Naumann GO. Bilateral zonular cataract associated with the mitochondrial cytopathy of Pearson Syndrome. Am J Ophthalmol 1998;125:260-1.

8. Lacbawan F, Tifft C], Luban NL, Schmandt SM, Guerrera M, Weinstein S, et al. Clinical heterogeneity in mitochondrial DNA deletion disordes: A diagnostic chalenge of Pearson syndrome. Am J Med Genet 2000;95:266-8.

9. Finsterer J. Hematological manifestations of primary mitochondrial disorders. Acta Haematol 2007;118:88-98.

10. Tarnopolsky M. Exercise testing as a diagnostic entity in mitochondrial myopathies. Mitochondrion 2004;4:529-42.

11. David DK. Miyopati. In: Delisa JA, Gans BM, editors. Fiziksel tıp ve rehabilitasyon ilkeler ve uygulamalar 4th ed. Ankara: Güneş Tıp Kitabevleri; 2007. p. 913-29.

12. Taivassalo T, De Stefano N, Chen J, Karpati G, Arnold D L, Argov Z. Short-term aerobic training response in chronic myopathies. Muscle nerve 1999;22:1239-43.

13. Trenell MI, Sue CM, Kemp GJ, Sachinwalla T, Thompson CH. Aerobic exercise and muscle metabolism in patients with mitochondrial myopathy. Muscle Nerve 2006;33:524-31.

14. Bodur H. Miyopati rehabilitasyonu. In: Oğuz H, Dursun E, Dursun N, editörler. Tıbbi rehabilitasyon. 2.baskı. Istanbul: Nobel Matbaacılık; 2004. p. 695-710. 